\title{
Boom Ahead for Graduate Education
}

The draft, the Students for a Democratic Society and cannabis permitting, the graduate schools are likely to be the most rapidly growing parts of the educational system in the United States during the years ahead. The scale of the expansion which is in prospect and the problems which it will create have now been well described in two reports published by the National Science Board-the board of trustees of the National Science Foundation, which has only now joined the throng of organizations in Washington giving public advice on matters of public policy. The board's recommendations are based on a study carried out by Dr Lawton M. Hartman (Graduate Education-Parameters for Public Policy, US Government Printing Office, $\$ 1 \cdot 25$ ). The views of the board, together with some dissenting opinions, are published as Toward a Public Policy for Graduate Education in the Sciences (US Government Printing Office, 40 cents).

The most striking part of the National Science Board's first essay into public policy is the series of far-reaching recommendations about the involvement of the Federal Government in university development and the support of scientific research. If these are accepted by the new administration, and if they do not raise too many hackles in Congress, the result could be a radical reshaping of the government's relationship with academic science.

The National Science Board is eloquent to the point of being flowery about the importance of graduate teaching. "American eivilization is increasingly dependent on the institutions and the products of graduate education", for example. It does, however, effectively marshal the evidence of rapid growth and increasing cost which Dr Hartman's survey has assembled. It does not shrink from the difficulties which rapid growth will create, but says that graduate education is not just a nuisance but a virtue. The report says that only by this means can an increasing proportion of the United States population be provided with full educational opportunity, that graduate education is the only means of making full use of scientific and engineering resources and that it will also determine "the contribution of American science and engineering to human welfare throughout the world".

Although the National Science Board has some homilies for the universities and for state and local governments, most of what it has to say is addressed to the Federal Government. The board asks that Washington should recognize that "it is in the national interest that there shall be colleges and universities in all regions of the nation that maintain programmes of high quality in graduate education ...".

The board is critical of some features of the means by which the Federal Government has so far endowed university research. Although recognizing the successes of the past few decades, the report says that the financial support of research has been "largely unrelated in concept to graduate education", with the result that the universities have been forced to compete for funds with very different kinds of institutions-industrial laboratories, nen-profit-making institutions and even government organizations.

The board is also worried by the danger that increased support of research by mission-oriented agencies could distort the pattern of graduate education-and also create unwarrantable stresses at times when agencies cut back on spending. The board also regrets the way in which the present system necessarily bolsters up the institutions which are already strong, and it considers that the dependence of university salaries on research grants "has had the effect of eroding faculty loyalties to the institution". By the same token, the making of research grants by bodies external to the universities may make it hard for students to follow their inclinations in research even though the board acknowledges that the practice also makes sure that they have practical experience of useful ficlds of work.

The board asks that there should be six separate programmes of Federal support for graduate cducation.

First, it asks that there should be "Institutional Sustaining Grants" designed to provide a financial platform for institutions engaged on graduate education. 'The board's objective is to make direct payments. for the sums of money which are at present collected as overhead components in research grants from Federal agencies. It singles out for separate mention the summer salaries of academic staffs, although it says that senior research workers engaged almost exclusively on research projects should continue to be paid through grants or contracts. The idea is that the amount of this payment to an institution should be calculated by a formula linking not merely the size and specialty of graduate schools but their quality as well.

Second, the board would like to see a system of "Departmental Sustaining Grants" designed to provide a measure of long-term support for those departments which, by some form of competition with their rivals, were able to demonstrate their competence and even excellence. The board considers that this method of financing would be especially important for such departments as those in mathematics, where salaries necessarily play an important part in total costs. This grant would cover the Federal contribution to students' stipends, costs of special equipment, the needs of young investigators newly appointed to the faculties and the costs of continuing programmes of research which promise to enhance the standing of the departments.

To help with the development of selectod graduate schools, the board would like to see a "substantial" programme of development grants intended to help "emerging" institutions and to win some of the economies of scale revealed by the statistics which have been assembled. Although these grants would be awarded, in the board's view, by national competition, it suggests that they would be a convenient instrument for influencing the geographical distribution of graduate schools. In much the same vein, the fourth recommendation is for a system of "Graduate Facilities Grants" to help build such things as specialized libraries or computer centres.

On the assumption that the Federal contribution towards the stipends of graduate students would be absorbed in departmental grants, the board looks to a system in which Graduate Fellowships would be awarded to between one and two per cent of the total graduate enrolment chiefly so as to single out especially promising young people. For the rest, the board would 
like to see the several Federal agencies continue to award research grants (overheads not included), and there is nothing in the report to suggest that the National Science Board wishes to see the number of grant-giving agencies reduced.

To judge from the dissenting opinions of five members of the board, the most controversial of these proposals-at least for scientists-will be the recommendations on Departmental Sustaining Grants. All the dissenters argue that there are inherent virtues in the system of project grants by which the proposals of investigators are scrutinized by colleagues, usually competitors as well, while some of the dissenters fear that a centralized system would also be slow to respond to the need for change.

Dr Hartman's study suggests that graduate education in the United States is still on the steeply rising part of a growth curve. The population of graduate students is expected to double between now and 1980, which implies the need to provide accommodation and equipment for an extra 700,000 graduate students. The report points out that this increase is actually greater than the total enrolment in American universities and colleges in the mid-twenties. The report refrains from comparisons with countries elsewhere, but it is a salutary fact that the number of postgraduate students at British universities at the end of 1966 amounted to 13,000 , of whom 47 per cent were working in the sciences. Although this figure does not include the large numbers of people working at colleges of education, it is a vivid reminder of the difference of scale between the two countries. Another indicator of the speed of growth of graduate studies in the United States is the ratio of undergraduates and graduates in the younger population in the United States. The rate

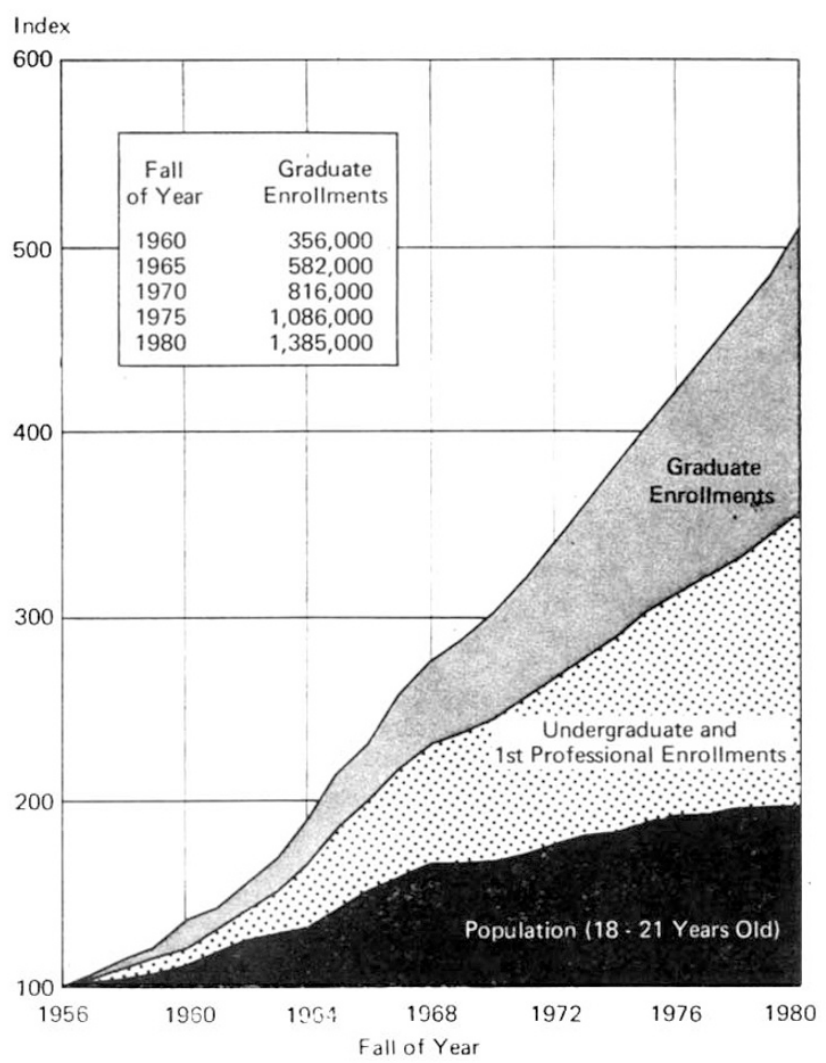

Fig. I. of graduation from high schools has reached 77 per cent, and there are now 43 undergraduates at colleges and universities for every 100 of the population between 18 and 21 . The graduate population is at present 12 per cent of the undergraduate population, and is expected to increase by 1976 to 14 per cent of what will be by then a proportionately still larger undergraduate population, no less than half the size of the age groups at risk.

Although the surveys which have been carried out provide plenty of evidence that growth will continue well into the seventies, the forward projections are based on the assumption that rates of growth in the educational system as a whole were faster in the early sixties than they will be in the next few years. In the period 1961-65, the graduate population was increasing at more than 10 per cent a year, compared with just under 9 per cent a year for the undergraduate population and 4 per cent a year for the age groups 18-21. By the late seventies, Dr Hartman estimates that the rate of growth of the graduate population will have declined to less than 4 per cent a year, but that it will still be greater than the rate of growth of the undergraduate population of universities and colleges.

Dr Hartman has no doubt of the availability of bright people to fill the growing graduate schools in the next few years, and he points out that the average $\mathrm{PhD}$ graduate scores 130 on the Army General Classification Test, from which it can be calculated that the number of people at present receiving doctorates is only 1.2 per cent of the section of the population which, by army standards at least, seems suitably endowed.

Table 1. MLEDAN TIME BETWEEN BACHELOR'S DEGREE AND PHD, 1964-66

$\begin{array}{lr}\text { Physical sciences } & 6.3 \text { years } \\ \text { Biological sciences } & 7.3 \text { years } \\ \text { Social sciences } & 8.0 \text { years } \\ \text { Arts and humanities } & 9.5 \text { years } \\ \text { Professional } & 10.8 \text { years } \\ \text { Education } & 13.8 \text { years } \\ \text { All ficlds } & 8.8 \text { years }\end{array}$

In the first few years of this decade, the median length of time spent on winning a $\mathrm{PhD}$ degree seems to have fluctuated between $8 \cdot 2$ and 8.8 years. The physical sciences seemed to be producing $\mathrm{PhD}$ degrees most quickly, with a median interval between bachelor's degree and $\mathrm{PhD}$ of $6 \cdot 6$ years. The corresponding intervals of time for other fields of study are shown in Table 1. One striking feature of Dr Hartman's analysis is that the median length of time spent on a PhD course amounts only to $5 \cdot 4$ years when both degrees are obtained at the same institution but to no less than 11.8 years for those students who obtain their first degree at one institution, a master's degree at a second and $\mathrm{a} P \mathrm{Ph}$ at yet a third.

The survey which the National Science Board has commissioned also ventures on the tricky task of ranking institutions awarding graduate degrees by quality. Dr Hartman's method of doing this is based on a study of graduate institutions carried out in 1966 by Dr A. M. Cartter. No doubt for the sake of peace and quiet, few details have been given of the method of determining quality, so that there will be no means by which institutions or their enemies can 
discover from the report who has obtained what grades.

Nobody will be surprised that there is a marked correlation between the quality of an institution and the amount which it receives from the Federal Government by way of grants for academic research and development. In the early sixties, the median grant to the best institutions amounted to close on $\$ 23$ million a year, falling away to rather less than $\$ 1$ million a year at the othor end of the quality scale. It is also unsurprising that fellowship awards from the National Science Foundation and other bodies should have tended to be made preforentially to students from the better institutions. In the fifteen years from 1952 to 1964 , the median proportion of successes in applications for fellowships was $0 \cdot 360$ at grade A institutions and $0 \cdot 197$ at grade $G$ institutions, with a regular decrease in between. Continuing this description of how largesse tends to improve the condition of those who are already reasonably well off, the survey shows that, in science and engineering, members of the graduate faculties at grade A institutions were able to obtain for their students a median of 0.429 doctoral awards-a ratio which falls steadily down the grades to $0 \cdot 133$ in grade $G$.

The institutions awarding graduate degrees seem to be readily distinguishable from each other by their internal structure. One striking variable is the percentage of full professors in the faculty, which ranges monotonically from 42 per cent at grade A institutions to 28 per cent at grade $G$ institutions. In the same way, there secms to be a steady decline of median salary with grade, at least for the higher ranking academies. In 1967-68, the median salary of full professors was greater than $\$ 19,000$ at grade $\mathrm{A}$ institutions and just under $\$ 14,000$ at grade $G$ institutions. In the lower ranks, however, institutions in all seven grades used in the survey seem to have paid median salaries of $\$ 8,000$ to instructors and $\$ 10,000$ to assistant professors.

A part of the objective of this painstaking analysis is to calculate the cost of improving the quality of graduate institutions. The nub of the conclusion is that promotion of a grade $\mathrm{B}$ institution to a grade $\mathrm{A}$ institution works out at $\$ 550,000$, spread out over 10 years, for each unit of annual $\mathrm{PhD}$ production. Judged by this criterion, it seems to be more economical to promote the quality of institutions of intermediate quality than to improve those at the bottom. Dr Hartman estimates that the years ahead will, however, see a considerable growth in the intermediate institutions, with tho result that the grade $\mathrm{A}$ institutions will be producing 19.8 por cent of all $\mathrm{PhD}$ graduates compared with 32.4 per cent in 1964-65.

The report is splendidly explicit about the cost of graduate education and about the likelihood that it will become even more expensive than it is at present. In 1951-52, the annual cost per student of graduato instruction seems to have been $\$ 2,840$, divided roughly three to two for instruction and research. By 1965 , the total cost had grown to $\$ 7,280$ a year per student, with research and instruction almost equally costly. By 1981, the projection gons, research will account for $\$ 9,700$ in a total cost of $\$ 16,900$. By that time, the cost of graduate education will amount to $1 \cdot 39$ per cent of the GNP (compared with 0.74 per cent at present) even if the GNP itself kceps on increasing at $5 \cdot 4$ per cent a year.

\section{UNIVERSITIES}

\section{Harvard goes to Town}

$A$ UNIVERSITy and the town that grows up around it form a chimerical community whose head and body have no natural wish to travel in precisely the same directions. Relations between town and gown may rarely become as bad as in Cambridge, England, when Honry III was obliged to send in troops to quell the riots. But, equally, they grow no better when the university, as in Cambridge, Massachusetts, practises a policy of studious noutrality towards the eity that encompasses it. A committee appointed by President Pusey has now concluded that Harvard University should develop a positive interest in the affairs of the City of Cambridge, taking steps not only to influence planning and housing prices with its real estate transactions, but also to act as an enlightened employer, landlord and neighbour (Preliminary Report of the Committee on the University and tine City, Harvard University).

The reasons for this ehange of face are not far to seek. The differences in the quality of life between the Harvard campus and the several slum areas that surround it are all too visible. This and such irritants as the price of housing, inflated by the university's presence, have kindled a new animosity to replace the historical antipathy between the Boston Irish and what they saw as the Brahminical community in their midst. The alarming incidenes of burglaries and crimes of violence is not a suitable part of a university atmosphere, and the Harvard faculty may already be apprehensive lest hostile hinterlands of the type that helped to engender the recent disturbances in Columbia and Chicago should grow up around the campus. Perhaps the most important impetus to change is the growing awareness of community problems among the student body. Graduate students in particular, who have to live off the campus, have been pressing for courses in urban studies and a greater concern with the city's affairs.

In its proposals the committee has been sympathetic to much of this feeling. The university, it points out, employs 13,000 people, spends $\$ 170$ million a year and occupies 350 acres of land; no institution of this size can be neutral about its environment. The committee recommends that a Vice-President for External Affairs, together with an advisory committee, should be appointed to direct the university's affairs as they affect the city. A fund, to be known as the Harvard Community Foundation, should be set up to finance social programmes in the area that might now otherwise attract support. In its staffing policies, the university should not be content with the proportion of its employees, currently three per cont, who are negro.

The committee respects the interest taken by students in urban studies, but believes it does not yet justify any radical changes in the university curriculum or organization, although existing programmes should be made more flexible and "better adapted to the proven interests of students and faculty alike". "Urban studies", the committee believes, does not have the makings of an academic discipline. Instead, a doctoral course in planning and policy analysis should be set up by the Kennedy School of Government, with central disciplines in economies, sociology and statistics. 